\title{
Pelaksanaan Pembelajaran Daring Pada Jenjang Sekolah Dasar
}

\author{
Anggita Putri Mulyani \\ E-mail: mulyanianggitaputri@gmail.com \\ *Program Studi Pendidikan Bahasa dan Sastra Indonesia, Universitas Riau
}

\section{Pengantar}

Sejak Indonesia dilanda pandemic covid-19 dikeluarkannya kebijakan pemerintah melalui Kementrian Pendidikan dan Kebudayaan bahwa seluruh kegiatan pendidikan dilaksanakan secara dalam jaringan dengan memanfaatkan berbagai teknologi yang tersedia. Ini tentunyu menuntut guru untuk mampu beradaptasi dan menemukan model pembelajaran yang selaras dengan teknologi yang digunakan.

Pembelajaran secara daring merupakan cara baru dalam proses belajar mengajar yang memanfaatkan perangkat elektronik khususnya internet dalam penyampaian belajar. Pembelajaran daring, sepenuhnya bergantung pada akses jaringan internet. Menurut Imania (2019) pembelajaran daring merupakan bentuk penyampaian pembelajaran konvensional yang dituangkan pada format digital melalui internet. Pembelajaran daring, dianggap menjadi satu-satunya media penyampai materi antara guru dan siswa, dalam masa darurat pandemi.

Dapat kita lihat bahwa banyak sekali terjadi kendala-kendala pelaksanaan pembelajaran daring yang perlu perhatian lebih oleh guru sebagai tenaga yang mentransferkan ilmu kepada peserta didik. Terdapat banyak sekali keluhan peserta didik yang dapat kita lihat pada berita-berita online, terlebih lagi ada petisi dari para peserta didik menuntut pembelajaran tatap muka segera dilaksanakan. Yang sering dieluh-eluhkan oleh peserta didik banyaknya tugas, keluhan datang dari orang tua yang perihatin terhadap pemahaman anaknya, serta hilangnya kreativitas peserta didik.

Perlu adanya inovasi dalam pelaksanaan kegiatan pembelajaran dengan memanfaatk berbagai media baik itu media online maupun media bentuk fisik 
sebagai bentuk menarik kembali perhatian peserta didik. Terlebih lagi peserta didik dijenjang sekolah dasar masi sangat terobsesi dengan kegiatan bermain. Maka perlu dirancang kegiatan belajar yang menyenangkan sehingga peserta didik bisa belajar sabil bermain dan mengembangkan kreativitasnya.

Penulis membuat tulisan ini dengan merujuk pada pelaksanaan pembelajaran daring di SD Negeri 004 Talang Danto sebagai acuan dengan sampel terdekat. penulis bertujuan agar pelaksanaan pembelajaran daring dapat terlaksana dengan optimal sehingga peserta didik dapat menyerap ilmu dengan sebaik-baiknya.

\section{Tindakan yang Dilakukan}

Dalam mewujudkan pembelajaran bahasa Indonesia yang efektif tentulah dibarengi dengan tindakan pula. Seorang guru mata pelajaran khususnya bahasa Indonesia, tentulah harus mampu mevairkan suasana dalam pelaksanaan kegiatan bisa itu dengan menanyakan pertanyaan ringan saat membuka kelas untuk mengecek bagaimana kesiapan pesrta didik jika terlihat peserta didik belum tertarik dengan materi bahasan tentunya guru harus sigap menciptakan inovasi agar perhatian peserta didik dapat sepenuhnya dalam menerima materi yang akan disampaikan.

Kemudian Guru memperlihatkan konten video yang telah dipersiapkan dengan memanfaatkan media video maker. Sehingga akan menarik perhatian peserta didik dan peserta didik dapat memperhatikan dengan seksama materi yang ditampilkan dan penyerapan materi akan lebih mudah diterima. Karena, bentuk ilustrasi visual yang bergerak mampu menstimulus otak agar merekam video ilustarasi materi yang diberikan.

Setelah selesai video ditanyangkan selanjutnya guru akan melempar pertanyaan kepada peserta didik terkait video materi sehingga tercipta suasana belajar yang komunikatif dan menyenangkan karena sejak awal peserta didik sudah meanruh perhatian pada materi bentuk video yang ditayangkan.

Untuk mengukur tingkat pemahaman peserta didik guru dapat memeberikan tugas kepada peserta didik dengan membuat video seperti yang telah ditayangkan sebagai tugas rumah. Melalui tugas ini juga dapat mengasah 
kreativitas peserta didik dengan memanfaatkan berbagai media dan video tersebut diunggah pada akun channel peserta didik yang diawasi oleh orang tuanya. Untuk ditanyangkan pada minggu berikutnya sebagai bentuk apresiasi.

\section{Sarana Pendukung}

Tak hanya tindakan yang diperlukan dalam pelakanaan belajar mengajar, tetapi sarana pendukung yang juga turut menjadi unsur penting dalam menciptakan suasana pembelajaran yang efektif pada mata pelajaran bahasa Indonesia. Sarana pendukung tersebut antara lain:

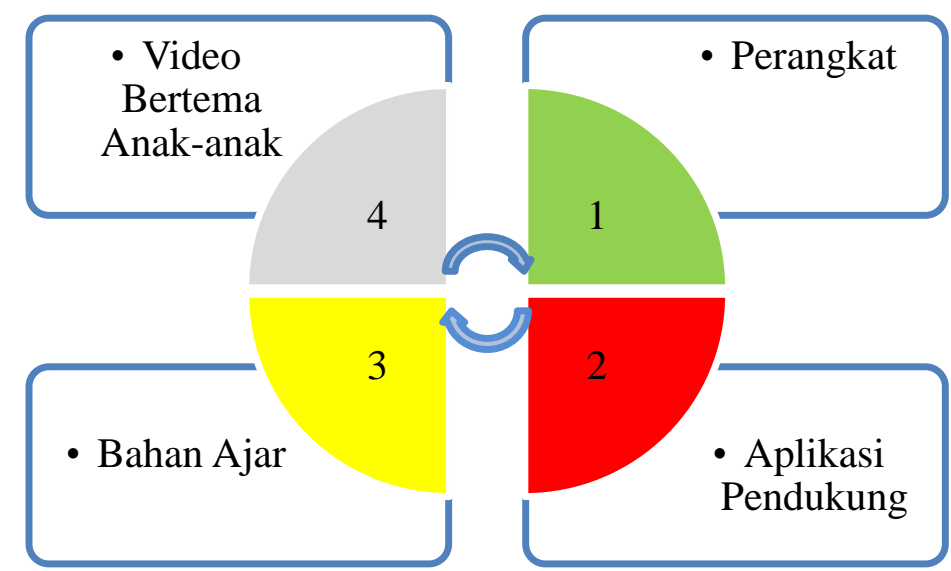

Gambar 1. Sarana Pendukung Pembelajaran Daring di Sekolah Dasar.

1. Perangkat, dalam pelaksanaan pembelajaran daring perangkat merupakan saran pertama yang harus di siapkan seorang tengana pendidik, perangkat ini dapat berupa computer atau laptop, kuota internet serta jaringan internet yang memadai. Sehingga proses pembelajaran dapat terlaksana dengan baik.

2. Aplikasi Pendukung, penggunaan aplikasi merupakan sarana umum yang sering digunakan guru dalam melaksanakan kegiatan pembelajaran, dapat berupa aplikasi Google classroom, Google meet atau zoom. Selanjutnya aplikasi pendukung video maker juga diperlukan karena pembelajaran yang berpusat pada pembuatan video kreatif pembelajaran.

3. Bahan ajar, sebagai seorang guru tentulah harus menyiapkan bahan ajar untuk digunakan dalam menyampaikan materi terkait. Bahan ajar ini merupakan sumber utama dari pembelajaran berupa, buku ajar dan buku latihan. 
4. Konten bertema anak-anak, karena pelaksanaan pembelajaran yang menggunakan visual video tentulah guru harus mempersiapkan video-vdeo pembelajaran bertema anak-anak guna menunjang proses pembelajaran dan menjadi inspirasi bagi peserta didik dalam pembuatan tugas video kreatif tersebut.

\section{Tindakan Solutif}

Selain sarana pendukung, guru bahasa Indonesia harus mampu sigap dalam menghadapai kendala dalam proses pelaksanaan pembelajaran . Guru harus mampu menyiapkan solusi terhadap kemungkinan-kemungkinan yang dapat menjadi penghalang dalam proses pembelajaran.

Karena kegiatan pembelajaran di SD Negeri 004 Talang Danto sudah dilaksanakan semi daring. Maka tindakan solutif ialah dengan secara lansung menyerahkan tugas pengumpulan link video kepada guru yang bersangkutan serta buku latihan.

\section{Simpulan}

Guru sekolah dasar memiliki tanatangan besar selama pembelajaran daring, dituntut mamou menciptakan pembelajaran yang menyenangkan serta mengahadapi peserta didik yang sedang asyik dengan dunia bermainnya. Dalam pelaksanaan pembelajaran dapat dengan tindakan yakni mengecek kesiapan pendidik dan peserta didik dalam menerima dan menyampaikan materi, memperlihatkan video kreatif pembelajaran materi sebagai bentuk menarik perhatian peserta didik, serta pemberian tugas pembuatan video kreatif pembelajaran untuk mengukur pemahaman peserta didik dan meningkatkan kreatifitasnya.

Selain dibarengi tindakan juga harus mempersiapkan sarana pendukung dan penyelesaian saat menemukan kendala dalam proses pelaksanaan pembelajaran. Saran pendukung antara lain perangkat, aplikasi pendukung, bahan ajar, dan video bertema anak-anak. Namun, pasti akan menemukan kendala terkait sarana pendukung tersebut, karena telah dilaksanaka pembelajaran semi daring 
maka peserta didik dapat lansung menyerahkan tugas mereka kepada guru yang bersangkutan.

\section{Referensi}

Muhibbin Syah. (2013). Psikologi Pendidikan: Dengan Pendekatan Baru. Bandung: Remaja Rosda Karya .

Mulyasa. 2013. Pengembangan dan Implementasi Kurikulum 2013.

Mustafa, M. N., \& Zulhafizh, Z. (2018). Information Mastery By Teachers As A Strategy To Succeed In The Implementation Of Teaching And Learning Activities. In International Seminar and Annual Meeting BKS-PTN Wilayah Barat 2018 (pp. 516-523), Palembang.

Mustafa, M. N., \& Zulhafizh. (2017). Building the Professionalism of Teachers as an Effort to Improve Education. In Husein, R, et al (Eds.), International Seminar and Annual Meeting 2017 Fields of Linguistics, Literature, Arts, and Culture, Medan, 449.

Rigianti, H. A. (2020). Kendala Pembelajaran Daring Guru Sekolah Dasar Di Banjarnegara. Elementary School: Jurnal Pendidikan dan Pembelajaran ke-SD-an, 7(2). 
*Data Penulis

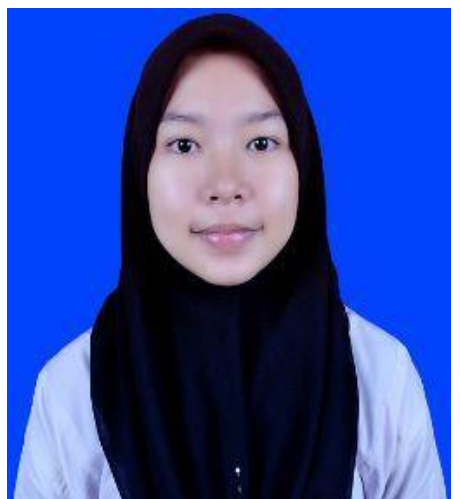

Anggita Putri Mulyani, lahir di Sidoarjo, 22 September 2002.

Pada tahun akademik 2020-2021 Ia melanjutkan studi pada strata satu Jurusan Pendidikan Bahasa dan Seni di Program Studi Pendidikan Bahasa dan Sastra Indonesia FKIP Universitas Riau melalui jalur SNMPTN, dan sampai sekarang masih berstatus mahasiswa. Ia aktif diorganisasi Himaprodi PBSI sebagai anggota divisi kesekretariatan periode 2021-2022.

Kontak:

Hp/WA : + 628535153

Email : mulyanianggitaputri@gmail.com 